\title{
Metal-Organic Frameworks for Sensing Applications in the Gas Phase
}

\author{
S. Achmann ${ }^{1^{\star}}$, G. Hagen ${ }^{1}$, R. Moos ${ }^{1}$, I. Malkowsky ${ }^{2}$, C. Kiener ${ }^{2}$ \\ ${ }^{1}$ Functional Materials, University of Bayreuth, 95440 Bayreuth, Germany \\ ${ }^{2}$ BASF SE, Ludwigshafen, Germany \\ * Corresponding author: \\ Phone: +49 92155 7412, Fax: +49 92155 7405, e-mail: Functional.Materials@uni-bayreuth.de
}

\begin{abstract}
Several materials of the class of metal-organic frameworks (MOF) were tested for their applicability in the field of gas sensors. In particular, impedimetric gas sensor devices were studied. Various sensor configurations were investigated in a frequency range of $1 \mathrm{~Hz}-10 \mathrm{MHz}$, and additional time-continuous measurements at $1 \mathrm{~Hz}$ were performed. In the temperature range from $120{ }^{\circ} \mathrm{C}$ to $240{ }^{\circ} \mathrm{C}$, the sensors were exposed to $\mathrm{O}_{2}, \mathrm{CO}_{2}, \mathrm{C}_{3} \mathrm{H}_{8}, \mathrm{NO}, \mathrm{H}_{2}$, ethanol and methanol concentrations and tested under various humidity conditions of the carrier gas $\mathrm{N}_{2}$. The materials did not show any signal to $\mathrm{O}_{2}, \mathrm{CO}_{2}, \mathrm{C}_{3} \mathrm{H}_{8}, \mathrm{NO}$, and $\mathrm{H}_{2}$. However, promising pronounced and reversible responses in the electric properties to changes in humidity were obtained for some selected MOF materials. Of particular interest is the linear response curve observed at $120^{\circ} \mathrm{C}$.
\end{abstract}

Keywords: metal organic frame work; MOF; impedance spectroscopy; humidity; gas sensor.

\section{INTRODUCTION}

Metal-organic frameworks are well-known for their ability to store quite large amounts of hydrogen [1,2] or for their use in gas purification applications [3]. The reason for high storage capacity of this materials class is its high specific surface area, resulting from its high and ordered porosity. As small molecules like hydrogen are only adsorbed and not covalently bound to the surface, they can be released completely, for example at lower partial pressures. In this work, the change of the capacity of the materials, caused by the adsorbtion or desorbtion of molecules on the inner surface of the MOF, is utilized to detect small amounts of gaseous analytes by monitoring the electric impedance of the material.

\section{EXPERIMENTAL}

\subsection{Sensor preparation}

Different types of metal organic frameworks were provided as powders or pelletized by the BASF Group. From these materials, two different sensor set-ups were prepared as described in Fig. 1. Materials in powder form were processed in thick film technology and applied on top of Au-interdigital electrodes (IDEs) via screen-printing. In this study, IDE structures with a line width and spaycing of $50 \mu \mathrm{m}$ were used (50/50 IDE). The electical connection to the measurement equipment was provided by two Au-wires, welded on top of the contact pads of the Au-IDEs (Fig. 1a).

The pellets $(\varnothing=6 \mathrm{~mm}, d=2 \mathrm{~mm})$ were contacted directly by metal-discs $(\varnothing=6 \mathrm{~mm})$. Contact to the analysis system was again provided by two Au-wires (Fig. 1b). 


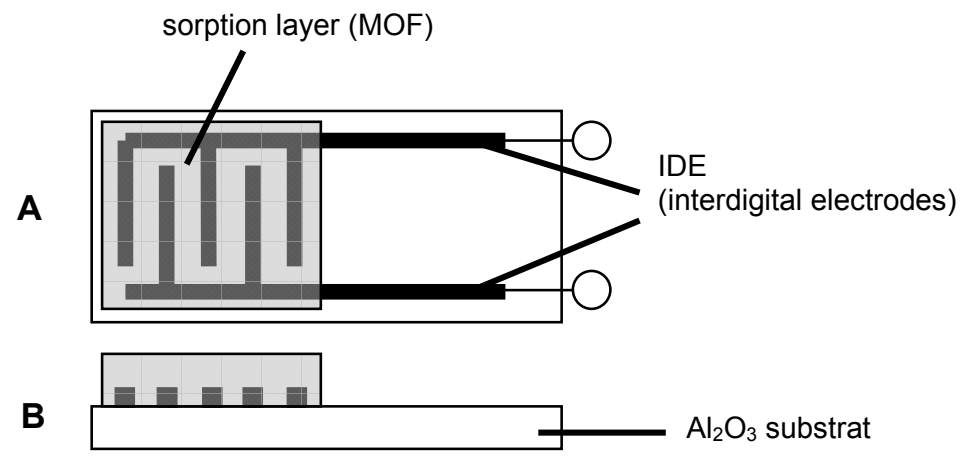

(a)

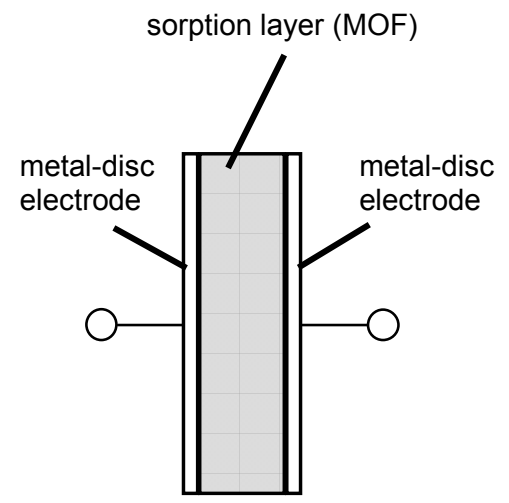

(b)

Figure 1. Sensor setup: (a) Sensor in thick film technology; MOF paste screen-printed on top of Au-interdigital electrodes (IDEs, 50/50), A: top view, B: cross section. (2) MOF pellet contacted by metal-disc electrodes.

\subsection{Sensor characterization}

Both sensor set-ups were passively heated in a furnace $\left(120^{\circ} \mathrm{C}-240^{\circ} \mathrm{C}\right)$ and characterized in $\mathrm{N}_{2}$ carrier gas similar to the method reported in [4]. Different gas concentrations of $\mathrm{O}_{2}, \mathrm{CO}_{2}, \mathrm{NO}, \mathrm{C}_{3} \mathrm{H}_{8}, \mathrm{H}_{2}$, ethanol, and methanol were admixed to the carrier gas (Table 1). For the variation of humidity of the test gas between 0 - $3 \%$ vol an assambly similar to [5] was utilized.

Table 1. Concentrations of test gas atmospheres.

\begin{tabular}{cc}
\hline test gas & $\begin{array}{c}\text { concentration of test gas } \\
\text { in } \mathbf{N}_{\mathbf{2}} \text { carrier gas }\end{array}$ \\
\hline $\mathrm{O}_{2}$ & $10 \%$ vol. \\
$\mathrm{CO}_{2}$ & $10 \%$ vol. \\
$\mathrm{NO}$ & $1000 \mathrm{ppm}$ \\
$\mathrm{C}_{3} \mathrm{H}_{8}$ & $1000 \mathrm{ppm}$ \\
$\mathrm{H}_{2}$ & $1000 \mathrm{ppm}$ \\
ethanol & $0-18 \% \mathrm{vol}$. \\
methanol & $0-35 \% \mathrm{vol}$. \\
\hline
\end{tabular}

An impedanze analyzer (Novocontrol) was used to monitor the frequency dependent impedancce of the sensor between $1 \mathrm{~Hz}$ and $10 \mathrm{MHz}$. In addition, time-continuous measurements were conducted at $1 \mathrm{~Hz}$, to evaluate the change of the complexe impedance or the capacity of the materials as a function of variations in the surrounding gas atmosphere. Gas atmospheres were monitored by an FTIR analysis system (Nicolet 6700 , Thermo) downstream the sensing device.

\section{RESULTS AND DISCUSSION}

None of the tested materials showed any cross-interfering effects in their electric properties at varying $\mathrm{O}_{2}$, $\mathrm{CO}_{2}, \mathrm{C}_{3} \mathrm{H}_{8}, \mathrm{NO}$ or $\mathrm{H}_{2}$ concentrations in the surrounding gas atmosphere. Sensor elements equipped with Fe-BTC-MOF showed significant effects when hydrophilic gases like ethanol, methanol and water were applied (Fig. 2). 

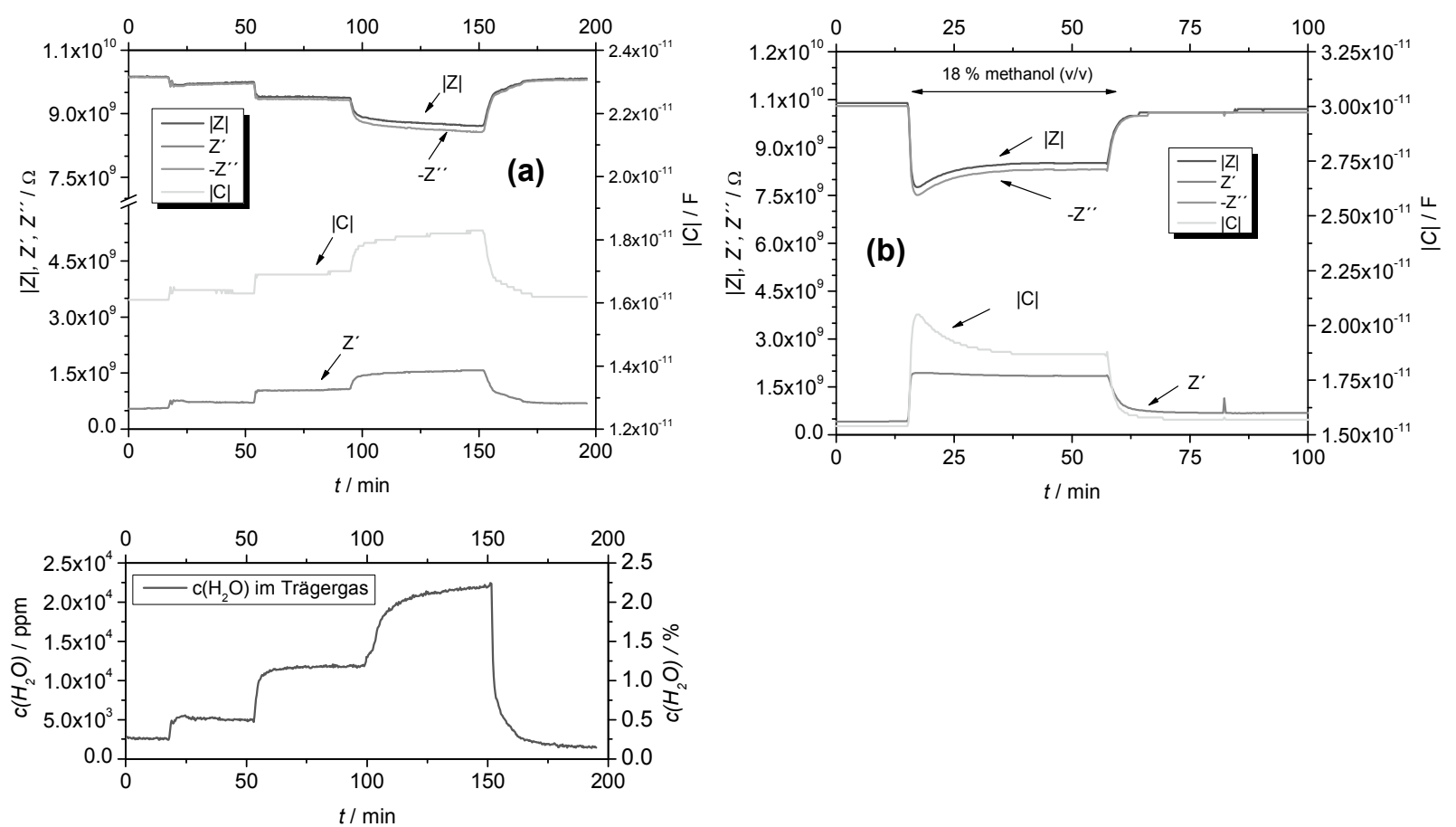

Figure 2. Characteristic impedimetric sensor signal for a Fe-BTC-MOF at different (a) $\mathrm{H}_{2} \mathrm{O}$ and (b) methanol concentration in the $\mathrm{N}_{2}$ carrier gas at $120^{\circ} \mathrm{C}$.

For example, at $120{ }^{\circ} \mathrm{C}$ there was a linear and reversible change in the complex impedance (IZI) of $1.5 \mathrm{G} \Omega$ when humidity was varied between $0-2.5 \% \mathrm{H}_{2} \mathrm{O}$ (Fig. 3a). With an increase in sensor temperature up to $240{ }^{\circ} \mathrm{C}$, the dependence of the sensor signal from the humidity of the surrounding gas can be approximated linear in a double logarithmic plot (Fig. 3b).

At $120{ }^{\circ} \mathrm{C}$, the response to the test gas increased in the order of methanol > ethanol $>\mathrm{H}_{2} \mathrm{O}$, whereby most stable and best reversible signals where obtained for variations in the water content.

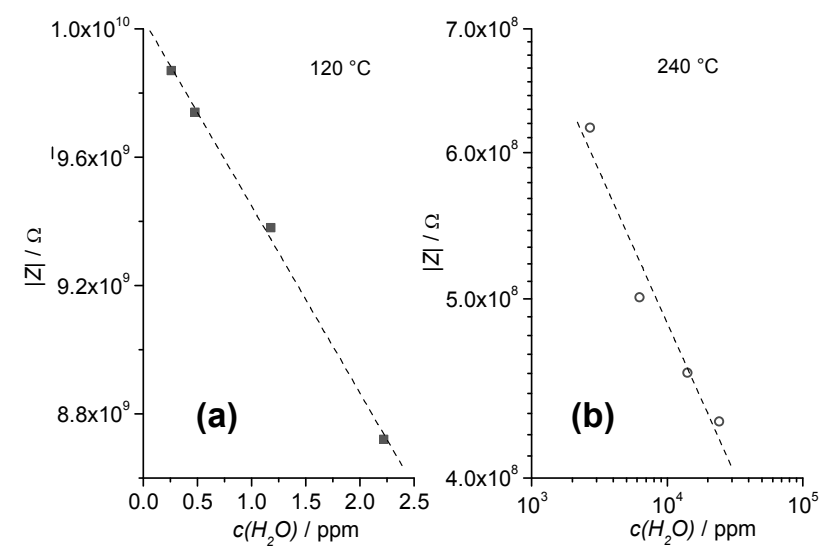

Figure 3. Sensor response curve for different concentrations of $\mathrm{H}_{2} \mathrm{O}(0-2.5 \%)$ in $\mathrm{N}_{2}$ carrier gas at $120^{\circ} \mathrm{C}$ and $240^{\circ} \mathrm{C}$. At $120^{\circ} \mathrm{C}$ a linear dependence of the complex impedance from the humidity of the test gas was observed. 


\section{CONCLUSION}

Different materials from the class of metal-organic frameworks have been investigated for the first time as sensor materials for impedimetric humidity sensors. In this study, metal-organic frameworks were identified as promising materials for the detection of hydrophilic gases in the atmosphere in a temperature range between $120-240^{\circ} \mathrm{C}$. Moreover, at $120^{\circ} \mathrm{C}$ a linear dependence of the sensor signal from the humidity of the test gas was observed. As MOFs can be synthesized as mass-products and can easily be applied to plain transducers via thick film technology, they are promising candidates for the application as recognition elements in gas sensors.

\section{REFERENCES}

1. Rowsell, J.L.; Yagi, O.M. Strategie für die Wasserstoffspeicherung in metall-organischen Gerüstmaterialien, Angew. Chem. 2005, 117, 4748-4758.

2. Latroche, M.; Surblé, S.; Serre, C.; Mellot-Darznieks, C.; Llewellyn, P.L.; Lee, J.-H.; Chang, J.-S.; Jhung, S.H.; Férey, G. Hydrogen storage in the giant-pore metal-organic frameworks MIL-100 and MIL-101, Angew. Chem. 2006, 118, 8407-8411.

3. Mueller, U.; Schubert, F.; Teich, F.; Puetter, H.; Schierle-Arndt, K.; Pastré, J. Metal-organic frameworks - prospective industrial applications, J. Mater. Chem. 2006, 16, 626-636.

4. Sahner, K.; Moos, R.; Matam, M.; Tunney, J.J.; Post, M. Hydrocarbon sensing with thick and thin film p-type conducting perovskite materials. Sensors and Actuators B-Chemical 2005, 108, 102-112.

5. Achmann, S; Hämmerle, M.; Moos, R. Amperometric enzyme-based gas sensor for formaldehyde: impact of possible interferences, Sensors 2008, 8, 1351-1365. 